\title{
ФОРМУВАННЯ ПРОФЕСІЙНОЇ КОМПЕТЕНТНОСТІ МАЙБУТНІХ ЛІКАРІВ ЯК ПЕДАГОГІЧНА ПРОБЛЕМА
}

\author{
Ya. M. Nakhaieva, I. R. Humenna, V. V. Shatsky \\ I. Horbachevsky Ternopil National Medical University \\ FORMATION OF PROFESSIONAL COMPETENCE OF FUTURE DOCTORS \\ AS A PEDAGOGICAL PROBLEM
}

\begin{abstract}
Анотація. Структура системи стандартів вищої освіти являє собою ієрархічну сукупність взаємопов'язаних стандартів, що встановлюють вимоги до змісту, обсягу та рівня якості вищої освіти. Сучасні працівники медичної галузі повинні мати міцні знання й уміння, навички, професійні якості та психолого-педагогічні здібності, що дають змогу знаходити оптимальні, самостійні рішення в нестандартних ситуаціях. У таких умовах лише професійно підготовлений лікар може вийти за межі незапланованого, наднормативного й ухвалити правильне, обгрунтоване рішення, а також нести за нього відповідальність. У статті розглянуто педагогічну проблему формування професійної компетентності майбутніх лікарів у медичних закладах вищої освіти. Окреслено термінологічну компетентність майбутніх лікарів як сформовану здатність доцільно використовувати фахові терміни під час професійної діяльності, розуміти й використовувати професійні висловлювання у різноманітних ситуаціях професійного спілкування з обов'язковим використанням фахової лексики, спираючись на досвід, отриманий під час навчання в університеті, та мотивуючи себе особистісною відповідністю обраному фаху і високими результатами у професійній діяльності. Термінологічна компетентність необхідна для професійної діяльності фахівця, вона міцно прив'язана до професії кожної галузі, визначаючи інваріантну частину базової компетентності фахівця.

Зроблено наголос на тому, що сучасні навчальні програми, які впроваджені внаслідок реформи медичної освіти, побудовані не лише за принципом здобуття знань та умінь, а й набуття компетенцій. 3’ясовано, що якість вищої медичної освіти встановлюється на основі професійної компетентності. Окреслено також теоретичні аспекти цієї проблеми.

Дослідження довело необхідність розробки методичних матеріалів для цілеспрямованого формування професійної підготовки майбутніх лікарів.
\end{abstract}

Ключові слова: професійна компетентність; компетенція; продуктивна освіта; стандартизація; інновації.

Abstract. The structure of the system of standards of higher education is a hierarchical set of interaction of interrelated standards that set requirements for the content, level and level of quality of higher education. Modern medical workers must have strong knowledge and skills, skills, professional qualities and psychological and pedagogical abilities that allow them to find optimal, independent solutions in nonstandard situations. In such conditions, only a professionally trained doctor can go beyond the unplanned, excessive and make the right, reasonable decision, as well as be responsible for it. The article considers the pedagogical problem of formation of professional competence of future doctors in medical institutions of higher education. The terminological competence of future doctors as the formed ability to use professional terms during professional activity is outlined, understand and use professional expressions in various situations of professional communication with the obligatory use of professional vocabulary, based on the experience gained while studying at university, and motivating themselves with personal compliance with the chosen profession and high results in professional activities. Terminological competence is necessary for the professional activity of a specialist, it is strongly tied to the profession of each field, defining the invariant part of the basic competence of a specialist.

Emphasis is placed on the fact that modern curricula, which have been introduced as a result of the reform of medical education, are built not only on the principle of acquiring knowledge and skills, but also the acquisition of competencies. It was found that the quality of higher medical education is established on the basis of professional competence. Theoretical aspects of this problem are also outlined.

The study proved the need to develop methodological materials for the purposeful formation of professional training of future doctors.

Key words: professional competence; competence; productive education; standardization; innovation.

(c) Я. М. Нахаєва, І. Р. Гуменна, В. В. Шацький 
Вступ. Інтеграція України до європейського освітнього простору потребує високого рівня професійної діяльності лікарів. Сучасні працівники медичної галузі повинні мати міцні знання й уміння, навички, професійні якості та психолого-педагогічні здібності, що дозволяють знаходити оптимальні, самостійні рішення в нестандартних ситуаціях. У таких умовах лише професійно підготовлений фахівець може вийти за межі незапланованого, наднормативного й ухвалити правильне, обгрунтоване рішення, а також нести за нього відповідальність.

Мета дослідження - розглянути педагогічну проблему формування професійної компетентності майбутніх лікарів у медичних закладах вищої освіти та окреслити теоретичні аспекти цієї проблеми.

Методи дослідження: теоретичний аналіз, узагальнення.

Результати дослідження. Проблема формування термінологічної компетентності майбутніх фахівців була предметом багатьох наукових досліджень. Зокрема, I. Бойцова вирішувала проблеми формування іншомовної комунікативної компетентності. Питанню професійної термінологічної лексики присвячені праці Є. Копіци, Н. Костриці, Л. Лучкіної та ін. Окремі аспекти розвитку термінологічної компетентності розглянуто в працях Н. Бондаренко, Т. Денищин, Е. Огар, Т. Симоненко та ін. Проблему формування професійно-термінологічної компетентності у процесі вивчення фахових дисциплін досліджували науковці І. Власюк, Л. Вікторова, Т. Бутенко та ін.

Усвідомлюючи нову роль освіти в сучасному суспільстві, доцільно виокремити актуальну для всіх країн світу проблему забезпечення і підвищення якості вищої освіти. Як зазначено у комюніке конференції міністрів, відповідальних за вищу освіту, якість вищої освіти лежить в основі розвитку загальноєвропейського простору вищої освіти. Задовольняючи освітні потреби особи та потреби суспільства у кваліфікованих фахівцях, держава повинна не тільки контролювати результати освітньої діяльності всіх її учасників на всіх етапах, а й гарантувати якість освіти. Проблема забезпечення якості, яка розглядається як сукупність характеристик суб’єкта діяльності, що стосуються його здатності задовольняти установлені та передбачені потреби освіти, є комплексною: науковою, технічною, економічною, соціальною [4, с. 123].

Якість вищої освіти встановлюється на основі професійної компетентності, а саме: за допомогою відповідності випускників медичного ЗВО динамічним вимогам соціально-економічної і культурно-професійної сфер життя. Звернення до проблеми формування професійної компетентності обумовлено підвищеними вимогами ринку праці до професіоналізму фахівця, а також такими змінами на ринку освітніх послуг, як конкуренція й упровадження нових технологій. Формування професійної компетентності має важливе значення в будь-якій сфері діяльності. Особливо гострою ця проблема постає тоді, коли готовність до певного виду професійної діяльності лише формується, знаходиться на стадії становлення, як це спостерігається під час професійної підготовки майбутніх лікарів. Так, сучасні перетворення в суспільстві вимагають від ЗВО медичного спрямування підготовки компетентного фахівця, який зуміє надати необхідну і своєчасну кваліфіковану допомогу.

Професійна компетентність лікаря розуміється як його інтегральна характеристика, що визначає здатність вирішувати різні проблеми і завдання 3 використанням знань, життєвого досвіду, прагнення до самовдосконалення як фахівця.

Професійна компетентність лікаря є сукупністю ключової, базової і спеціальної компетентностей. Ключові компетентності необхідні для будь-якої професійної діяльності, вони пов'язані з успіхом особистості в сучасних умовах і реаліях життя. Сьогодні ключові компетентності набувають особливої значущості. Перш за все, вони виявляються у здатності вирішувати професійні завдання на основі використання інформації, комунікації, зокрема іноземною мовою, у соціально-правових основах поведінки особистості в цивілізованому суспільстві [2, с. 127]. Ключова компетентність виявляється не лише у вирішенні вузькопрофесійних завдань, але й у тому, як фахівець сприймає, оцінює і розуміє світ за межами своєї професії.

Базові компетентності відображають специфіку певної професійної діяльності, наприклад, медичної. Для професії лікаря базовими $€$ компетентності, необхідні для організації професійної діяльності медичного працівника в контексті сучасних вимог до системи охорони здоров'я [1, с. 281].

Спеціальні компетентності відображають специфіку певної сфери професійної діяльності. Спеціальні компетентності можна розглядати як реалізацію ключових і базових компетентностей у конкретній галузі професійної діяльності. Усі три види компетентностей взаємопов'язані і розвиваються одночасно. Це і формує індивідуальний стиль професійної діяльності лікаря, створює цілісний образ 
медичного працівника з вищою освітою і забезпечує становлення його професійної компетентності як певної цілісності, як інтеграційної, особистісної характеристики.

Компетенції - це узагальнені способи дій, що забезпечують продуктивне виконання професійної діяльності [1, с. 351]. Щодо медичної діяльності, вона відображає здібність лікаря реалізовувати на практиці професійну компетентність. Групи компетенцій служать фундаментом, який дозволяє майбутньому лікарю чітко орієнтуватися на ринку праці і бути підготовленим до самоосвіти, додаткового й післядипломного навчання.

На якість вищої освіти впливає багато факторів, які діють самостійно або у взаємозв’язку між собою. Важливим механізмом гарантії якості є її стандартизація.

Стандартизація належить до комплексно пов’язаних із широким колом питань, від яких залежать цінність стандартів та їхній вплив на якість освіти. Як показали дослідження, стандартизацію можна розглядати як організовану діяльність з метою досягнення оптимального рівня упорядкування в певній галузі шляхом установлення положень для загального і багаторазового використання щодо реально існуючих чи можливих завдань. Вона $є$ унікальною сферою суспільної діяльності, що синтезує в собі наукові, технічні, господарські, економічні, юридичні, естетичні й політичні аспекти.

Принцип дії стандартів, які є організаційно-технічною основою системи управління і контролю якості, грунтується на тісному взаємозв’язку і взаємозумовленості усіх її елементів, що забезпечують стабільно високу результативність.

Процес створення, упровадження і дотримання єдиної системи показників якості з метою упорядкування діяльності є складним багатокомпонентним завданням, яке має бути змістовно й економічно обгрунтованим.

Відомо, що впровадження стандарту є доцільним, якщо воно дає очікувану результативність. Економічна ефективність від стандартизації освіти визначається на основі тих самих принципів, що й економічний ефект науково-технічного прогресу, складовою частиною якого є стандартизація [3, с. 66].

Структура системи стандартів вищої освіти являє собою ієрархічну сукупність взаємопов'язаних стандартів, що встановлюють вимоги до змісту, обсягу та рівня якості вищої освіти. Основний компонент державних стандартів вищої освіти лікарів визначає структуру переліку напрямів та спеціальностей, за якими здійснюється підготовка фахівців у медичних закладах вищої освіти за відповідними освітньо-кваліфікаційними рівнями, а також вимоги до кожного освітньо-кваліфікаційного рівня та відповідного освітнього рівня.

Уведення системи стандартів сприяє підвищенню рівня організації та якості вищої освіти, дозволяє ефективно реалізувати єдину державну політику в галузі освіти, захищає інтереси споживачів освітніх послуг, забезпечує взаємозамінність та сумісність різних освітньо-кваліфікаційних рівнів, створює умови для інтеграції національної системи вищої освіти у міжнародне науково-освітнє співтовариство. Йдеться про ступінь стандартизації вищої освіти, який у даному випадку розглядається як нормативна база функціонування системи вищої освіти, яка встановлює загальні принципи майбутньої професійної діяльності лікаря, що має на меті досягнення оптимального рівня упорядкування в галузі вищої медичної освіти [3, с. 67].

Упровадження єдиних і обов'язкових для всіх навчальних закладів державних стандартів дозволяє зберігати єдиний освітній простір, досягти оптимального рівня впорядкування діяльності в галузі вищої освіти, але, як і попередні державні стандарти, не вирішує проблему наступності програм підготовки молодших спеціалістів і бакалаврів. Відсутність узгодженості цих стандартів не дозволяє особі, що має диплом молодшого спеціаліста, продовжувати навчання за затвердженою державою програмою. Здобувати наступний рівень освіти вона може за так званою «скороченою» програмою, що розробляється $3 В О$ в індивідуальному порядку, шляхом перезарахування вже вивчених дисциплін або їх розділів. Положення про освітньо-кваліфікаційні рівні (ступеневу освіту) лише гарантує, що термін підготовки їх за наступним освітньо-кваліфікаційним рівнем «бакалавр» зменшується на один - два роки. Це дає змогу зробити припущення про різну якість підготовки бакалаврів на базі повної загальної середньої освіти і на базі молодшого спеціаліста, а звідси - необхідність або розробки додаткового державного освітнього стандарту, або вилучення освітньо-кваліфікаційного рівня «молодший спеціаліст» із системи вищої освіти країни. Така модернізація буде відповідати стратегії розвитку освіти в Україні в частині забезпечення її якості на основі додержання державних стандартів освіти [3, с. 68].

Термінологічно-поняттєвий апарат у кожній професійній діяльності різний. Тому, на нашу думку, формування термінологічної компетентності, яка $\epsilon$ однією з основних складових професійної компе- 
тентності, є важливим етапом у підготовці кваліфікованого фахівця. Адже володіння термінологічнопоняттєвим апаратом належить до категорії спеціальних знань, без опанування яких неможлива успішна професійна діяльність майбутніх фахівців. Рівень володіння цим апаратом вказує на розуміння фахівцем професійних явищ і понять у сфері діяльності. Вміння спілкуватися мовою професії сприяє швидкому засвоєнню фахових дисциплін, підвищує ефективність праці, допомагає орієнтуватись у професійній діяльності та в ділових контактах. Однією із причин недостатнього рівня професійної підготовки фахівця є недооцінювання термінологічного аспекту в опануванні фахової термінологічної бази.

Тому, ураховуючи вищезазначене та на основі вивчення наукової літератури й узагальнення результатів змісту професійної медичної діяльності, відповідно до стандартів вищої медичної освіти виокремлюємо такі групи компетенцій, які передбачають сформованість певних компетентностей: - загальнонаукові, інструментальні та інформаційно-комунікативні компетенції відображають спрямованість на формування ключових компетентностей лікаря;

- загальнокультурні, соціальні, управлінські, цивільно-правові, методологічні, пізнавальні і загальнопрофесійні компетенції передбачають формування базової компетентності медичного працівника;

- орієнтовані, соціально-особистісні і персональні компетенції спрямовуються на спеціальну компетентність медичного фахівця.

Компетентність лікаря ми розглядаємо і як складову готовності лікаря до нововведень. Проте, як показують дослідження, при формуванні професійної компетентності медика особливе місце відводиться психологічному забезпеченню підготовки фахівця. Ми досліджували проблему психологічного забезпечення у підготовці майбутнього лікаря, що, на думку М. Садової, сприятиме формуванню та підтриманню у студентів адекватного рівня психологічної готовності до нововведень [5, с. 94].

Важливо підкреслити, що сума показників психологічної готовності до нововведень окремих студентів не тотожна готовності групи. Соціальнопсихологічна характеристика конкретних груп $€$ фактором, здатним самим істотно вплинути на можливість актуалізації інноваційного потенціалу навчального закладу. Тому психологічна готовність майбутнього фахівця є важливою сходинкою в досягненні загального успіху.
Як планові зміни, так і зміни в рамках організаційного розвитку припускають інформаційне забезпечення, яке дозволяє оптимізувати в цілому процес навчальних нововведень і підвищити рівень професійної готовності студента медичного закладу вищої освіти. У кінцевому підсумку йдеться про можливість більш повної реалізації стратегічного потенціалу до навчальної діяльності, тобто їі здатності продуктивніше розвиватися.

Постійна спрямованість студента на вдосконалення себе як суб’єкта майбутньої професійної діяльності звертає особливу увагу лікаря на недосконалість організаційного аспекту праці. Актуалізує можливість спільної діяльності викладачів і психолога, що створить передумови не тільки для постійного залучення студентів у колективну роботу та формуватиме установку майбутніх лікарів до змін як передумови поліпшень у напрямі професійного зростання. Таким чином залучення студентів до самозмін спонукатиме майбутніх лікарів здобувати нові знання та набувати вміння відповідно до вимог освітніх програм [5, с. 97].

Передбачаємо, що проведення навчальних заходів, орієнтованих на підвищення інноваційної готовності майбутніх фахівців медичного 3ВО, створюватиме психологічну основу формування установки на розвиток.

Висновки та перспективи подальших досліджень. Виходячи з наведеного аналізу, можемо зробити такі висновки: ключова компетентність складає інваріантну частину професійної компетентності майбутнього лікаря і спирається на вміння, необхідні для його освітньої діяльності. Базова компетентність потрібна для здійснення професійної діяльності фахівця медицини, вона міцно прив'язана до професії лікаря, а також застосовується представниками інших професій, визначаючи інваріантну частину базової компетентності фахівця. Спеціальна компетентність відіграє провідну роль у здійсненні конкретного виду професійної діяльності. Спеціальна компетентність складає варіативну частину професійної компетентності медичного працівника. Таким чином, тільки частина зробленого стосується оцінки рівня готовності до професійної діяльності майбутніх лікарів, діагностики мотивації до навчальної інноваційної діяльності і може бути предметом відкритого обговорення.

Перспективи подальших наукових пошуків вбачаємо у розробці методичних матеріалів для цілеспрямованого формування професійної підготовки майбутніх лікарів. 


\section{Список літератури}

1. Алексюк А. М. Педагогіка вищої освіти України. Історія. Теорія / А. М. Алексюк. - К. : Либідь, 1998. - 560 с.

2. Біловус Л. І. Пізнавальні властивості педагогічної комунікації / Л. І. Біловус, О. Є. Гомотюк, Н. О. Федчишин // Медична освіта : наук.-практ. журн. / голов. ред. Н. О. Федчишин. - Тернопіль : ТНМУ, 2020. № 3 (88). - С. 126-130.

3. Бондар В. I. Дидактико-психологічна концепція реалізації освітньо-професійних програм підготовки вчителя / В. І. Бондар // Вища освіта України. - 2004. № 1. - С. 66-68.

\section{References}

1. Aleksiuk, A.M. (2000). Pedahohika vyshchoi osvity Ukrainy. Istoriia. Teoriia [Pedagogy of higher education in Ukraine. History. Theory]. Kyiv: Lybid [in Ukrainian].

2. Bilovus, L.I., Homotiuk, O.Ie., \& Fedchyshyn, N.O. (2020). Piznavalni vlastyvosti pedahohichnoi komunikatsii [Gognitive features of pedagogical communication]. Medychna osvita - Medical Education, 3 (88), 126-130 [in Ukrainian].

3. Bondar, V.I. (2004). Dydaktyko-psykholohichna kontseptsiia realizatsii osvitno-profesiinykh prohram pidhotovky vchytelia [Didactic and psychological concept of implementation of educational and professional teacher training programs]. Vyshcha osvita Ukrainy - Higher Education in Ukraine, 1, 66-68 [in Ukrainian].
4. Мельничук I. М. Професійна підготовка майбутніх логопедів як медична і педагогічна проблема в історичному контексті / I. М. Мельничук // Медична освіта : наук.-практ. журн. / голов. ред. Н. О. Федчишин. - Тернопіль : ТНМУ, 2019. - № 3 (83). - С. 123-127. - 160 с.

5. Садова М. А. Духовно-моральні цінності та особливості процесу їх засвоєння особистістю / М. А. Садова // Проблеми загальної та педагогічної психології. - 2010. № 7 (12). - С. 91-98.

4. Melnychuk, I.M. (2019). Profesiina pidhotovka maibutnikh lohopediv yak medychna i pedahohichna problema v istorychnomu konteksti [Professional training of future speech therapists as a medical and pedagogical problem in a historical context]. Medychna osvita-Medical Education, 3 (83), 108-112 [in Ukrainian].

5. Sadova, M.A. (2010). Dukhovno-moralni tsinnosti ta osoblyvosti protsesu yikh zasvoiennia osobystistiu [Spiritual and moral values and features of the process of their assimilation by the individual]. Problemy zahalnoi ta pedahohichnoi psykholohii - Problems of General and Pedagogical Psychology, 7 (12), 91-98 [in Ukrainian]. 